\title{
Discussion of the Paper by David A. Scola, M.D. on "The Hemispheric Specialization of the Human Brain and Its Application to Psychoanalytic Principles"
}

\author{
Howard Field, M.D. \\ Thomas Jefferson University Hospital \\ Paul J. Fink, M.D. \\ Thomas Jefferson University Hospital \\ Thomas Swirsky-Sacchetti, Ph.D. \\ Thomas Jefferson University Hospital
}

Follow this and additional works at: https://jdc.jefferson.edu/jeffjpsychiatry

Part of the Psychiatry Commons

Let us know how access to this document benefits you

\section{Recommended Citation}

Field, M.D., Howard; Fink, M.D., Paul J.; and Swirsky-Sacchetti, Ph.D., Thomas (1984) "Discussion of the Paper by David A. Scola, M.D. on "The Hemispheric Specialization of the Human Brain and Its Application to Psychoanalytic Principles"," Jefferson Journal of Psychiatry. Vol. 2 : Iss. 1 , Article 6.

DOI: https://doi.org/10.29046/JJP.002.1.002

Available at: https://jdc.jefferson.edu/jeffjpsychiatry/vol2/iss1/6

This Article is brought to you for free and open access by the Jefferson Digital Commons. The Jefferson Digital Commons is a service of Thomas Jefferson University's Center for Teaching and Learning (CTL). The Commons is a showcase for Jefferson books and journals, peer-reviewed scholarly publications, unique historical collections from the University archives, and teaching tools. The Jefferson Digital Commons allows researchers and interested readers anywhere in the world to learn about and keep up to date with Jefferson scholarship. This article has been accepted for inclusion in Jefferson Journal of Psychiatry by an authorized administrator of the Jefferson Digital Commons. For more information, please contact: JeffersonDigitalCommons@jefferson.edu. 


\title{
DISCUSSION OF THE PAPER BY DAVID A. SCOLA, M.D. ON "THE HEMISPHERIC SPECIALIZATION OF THE HUMAN BRAIN AND ITS APPLICATION TO PSYCHOANALYTIC PRINCIPLES"
}

\author{
HOWARD FIELD, M.D.
}

\begin{abstract}
Dr. Scola proposes a bold and far-reaching synthesis of psychoanalytic theory, developmental neurobiology and neurophysiology of behavior. Freud found this task so frustrating in 1895 that he renounced neurology in favor of a purely psychologic approach (or so Freud claimed; Frank Sulloway sees it differently). Hypotheses that unconscious mental life is situated in the right cerebrum and that defense mechanisms are related to neuroanatomic connections are intriguing. The presentation does not include evidence which contravenes these theories. Sperry presented some evidence that the right hemisphere is self-aware and self-evaluative (1). One great problem in all cross disciplinary studies is the difference in terminology and definitions from various fields.

Now that Dr. Scola has set forth his theory, the real work begins: to collect data to substantiate it. The first and most direct method is the classical neurologic observation of patients with specific lesions. This method has been used from the time of Wernicke and Freud himself, down to the late great Alexander Luria. Epidemiologic data such as that linking familial tendency to dyslexia, autoimmune disease, migraine and lefthandedness may be important. Finally, the opportunity to do careful experimental work may come, such as that which won Sperry the Nobel Prize in 1981.
\end{abstract}

1. Sperry, R: Some effects of disconnecting the cerebral hemispheres. Science 217: 1223, 1982

Dr. Field is clinical Professor of Psychiatry.

\section{PAUL J. FINK, M.D.}

Needless to say, I am very proud of Dr. Scola's work and the creativity which he demonstrated in trying to wed a highly advanced biological theory of brain segmentation, i.e. laterality, with the psychoanalytic concepts of dream interpretation and free association. It is a credit both to him and our program that he could attempt to bring these two areas together in a single paradigm.

While reading this paper, I found myself constantly free associating to Julian 
Jaynes' extraordinary book entitled The Origins of Consciousness and the Breakdown of the Bicameral Mind. In a way Dr. Scola has begun to do in the present and for psychiatry what Dr. Jaynes attempted to do in the areas of evolution, art, history and world literature. Dr. Jaynes' thesis is that the mind as we know it with connections between the right and left hemispheres evolved through 3000-6000 years. He contends that in primitive times there was no corpus callosum or connection between the hemispheres and for one side of the brain to communicate with the other, the image or thought had to be projected out as a hallucination and then dealt with by the rational side of the brain which observed the hallucinatory picture and/or words. I am sure that I am oversimplifying Jaynes' thesis, but it is important to relate the work of Jaynes with Dr. Scola's ideas.

I hope that Dr. Scola will pursue his ideas with sound and well designed research. The possibilities are too numerous to mention. His ideas regarding the immature child and the immature brain are extremely important. Perhaps we could show that this slow and gradual myelinization of the corpus callosum is on a fixed timetable which can be enhanced by early infant stimulation or delayed perhaps irreparably by a poor and nonstimulating environment (shades of Rene Spitz!). Has Dr. Scola provided us with a clue to functional retardation?

Similarly, we have teleologically accepted Kris' concept of regression in the service of the ego. We do know clinically that artists are able to reach deep into their unconscious (primary process) minds and return to normal secondary process without suffering intercurrent psychosis. They produce innovative, creative products from this so-called regression. Following Dr. Scola's thesis, an artists' temporary regression may reflect a greater number of associative neurons traveling through the corpus callosum, perhaps derived genetically, perhaps derived developmentally. Maybe they have a thinner or more permeable corpus callosum.

Thinness and thickness should not be sneered at. A recent study demonstrated that schizophrenics, usually thought to have no anatomic abnormalities, have thicker corpora callosa than non-schizophrenics. Julian Jaynes would say that schizophrenia is a present-day representative of primitive man caused by an inability to think clearly, reason and connect images (right brain) with logical thought (left brain). What would David Scola say?

The future of psychiatry rests in the hands of Dr. Scola and his generation. Combining brain and mind, psychodynamics and biochemistry is the only way that our art and science can be presented as equal partners in our extraordinary profession.

Dr. Fink is Professor and former Chairman.

\section{THOMAS SWIRSKY-SACCHETTI, Ph.D.}

Dr. Scola's paper represents a creative and heretofore largely ignored effort to establish the neuropsychological underpinnings of psychoanalytic theory and practice. 
The study of brain-behavior relationships, which was once almost exclusively based on patients with brain pathology, is now moving quickly into the realm of normal brain functioning due to technological advances such as Positron Emission Tomography. This technique affords us a view of the brain at work and thereby can elucidate not only the neurophysiological activations involved in cognition and behavior, but also the neuropsychological aspects of personality dynamics. It is on this frontier which Dr. Scola reviews data concerning specialization in hemisphere functiong particularly as it relates to dreams, their interpretation, and free association.

Dr. Scola would agree that the hypotheses put forth in his paper are tentative. Much more information is needed before mechanisms as complex as conscious and unconscious states are fully understood. Although there are well documented and certain widely accepted ways in which the cerebral hemispheres differ in terms of style and content of information processed, it seems an oversimplification to view the right hemisphere as an "unconscious" or "processor of negative affect" and the left hemisphere as "judgemental" or "conscious." Recent research suggests that there is a great deal of flexibility in hemispheric specialization. For example, the right hemisphere has been shown to be involved in certain aspects of language, which was once thought to exclusively be the province of the left hemisphere. Naturally, there are occasionally profound inter and intra-individual differences in the way we process information, which further complicates the picture.

More importantly, however, Dr. Scola is to be commended for providing us with an extremely interesting and tenable beginning, with a way of viewing patients and therapeutic techniques in a completely different paradigm. The cross-fertilization and integration of these paradigms may well demonstrate that psychoanalytic theory and practice, considered by some to be outmoded, is a province we are just beginning to understand.

Dr. Swirsky-Sacchetti is Instructor in Psychiatry and Human Behavior (Psychology). 